\title{
FENOMENA DAN DAMPAK PARTISIPASI MASYARAKAT DALAM BEROLAHRAGA DI KAWASAN CAR FREE DAY (CFD) DI KOTA BESAR (STUDI PADA KOTA SEMARANG, SURABAYA, SURAKARTA)
}

\author{
Fery Darmanto ${ }^{1}$, Andry Akhiruyanto ${ }^{2}$, Heny Setyawati ${ }^{3}$, Agus Widodo Suripto $^{4}$ \\ ${ }^{1234}$ Jurusan Pendidikan Jasmani Kesehatan dan Rekreasi, Universitas Negeri Semarang, Semarang, Indonesia \\ *fernabil_hok@yahoo.com
}

(Received: January 2019 / Revised: March 2019 / Accepted: March 2019)

\begin{abstract}
ABSTRAK: Tujuan penelitian ini adalah mendeskripsikan tentang fenomena kegiatan olahraga yang dilakukan dikawasan CFD (Car Free Day) di Kota besar. Penelitian ini adalah penelitian kualitatif dengan menggunakan pendekatan deskriptif, dengan desain korelasional yang bertujuan menghubungkan dua variabel atau lebih, sedangkan teknik pengumpulan data menggunakan metode observasi, wawancara, pengumpulan dokumen lalu dianalisisi dengan reduksi data, penyajian data dan penarikan kesimpulan. Hasil dan kesimpulan dalam penelitian ini sebagai berikut fenomena yang terjadi di kota besar adalah $80 \%$ responden datang ke CFD dengan berkelompok dan membawa peralatan olahraga seperti bola, tali atau sepeda angina dari rumah, $86 \%$ responden datang rata-rata 2-3 kali dalam sebulan dan menghabiskan waktu selama 2 jam dikawasan CFD untuk berolahraga dan aktivitas lainnya. Dampak yang terjadi adalah $23 \%$ responden merasa senang dan terhibur dengan olahraga di kawasan CFD, sedangkan $72 \%$ responden merasa mendapatkan semangat dan motivasi baru sepulang dari olahraga dikawasan CFD dan 5\% responden merasakan hal yang biasa saja. Rekomendasi dari penelitian ini adalah untuk pemerintah kota dan kabupaten di Indonesia untuk mengadakan lebih banyak kegiatan CFD di daerahnya, untuk mengurangi dampak polusi kendaraan, meningkatkan kebugaran publik dan menjadi tempat hiburan yang menyenangkan bagi masyarakat.
\end{abstract}

KATA KUNCI: $\quad$ Fenomena dan Dampak dan, Car Free Day, Olahraga.

ABSTRACTS: The purpose of this study was to describes the phenomenon of sports activities conducted in CFD areas in big cities. This research is qualitative research used descriptive approach by correlational design whose purpose was to connect two or more variables that was by describing how the phenomenon and the impact of community participation in sports activities in car free day areas in big cities. Techniques of data collt is $23 \%$ of respondents feel happy and entertained with the sport activities in the CFD area, while $72 \%$ of respondents feel getting the spirit dan new motivation coming from sports area and 5\% respondents feel the usually. The recommendation of this research is to city and district governments in Indonesia to hold more CFD activities in their area, to reduce the impact of vehicle pollution, improve public fitness and become a fun entertainment place for the community.

KEYWORD:

Phenomenon, Impact, Car Free Day.

\section{PENDAHULUAN}

Dengan majunya teknologi di dunia hal ini memudahkan semua kegiatan manusia menyebabkan kita kurang gerak (Hypokinetic) seperti penggunaan remot kontrol, komputer, lift dan tangga berjalan tanpa diimbangi dengan aktifitas fisik yang akan menimbulkan penyakit kurang gerak, Maka dalam upaya dalam meningkatkan kebugaran dan derajat Hipokinetik adalah penyakit yang timbul karena kurang gerak seperti jantung coroner, hipertensi, obesitas, kecemasan (Nurhasan 2013). Dengan kemajuan Iptek saat ini dapat mempengaruhi menurunnya tingkat kesegaran jasmani seseorang (Irianto, 2000). kesehatan masyarakat diperlukan aktivitas fisik atau olahraga yang merupakan kebutuhan pokok Hal ini juga sejalan dengan program 
Journal of Sport and Exercise Science, Vol 2, No 1, 2019 (14-20)

Fenomena Dan Dampak Partisipasi Masyarakat Dalam Berolahraga Di Kawasan Car Free Day (CFD) Di Kota Besar (Studi Pada Kota Semarang, Surabaya, Surakarta)

pemerintah dalam memberlakukan program Car Free Day dalam mengurangi polusi diperkotaan dan salah satu cara dalam memelihara kesehatan masyarakat.

Suatu terobosan baru telah dilakukan pemerintah untuk menjaga dan meningkatkan kualitas lingkungan kota yaitu dengan memberlakukan program Car Free Day atau hari bebas kendaraan lingkungan (HBKB). Program ini melibatkan peran masyarakat untuk lebih aktif dalam upaya menciptakan suasana yang lebih bersih, bebas dari polusi, selain itu Car Free Day adalah salah satu program dalam menjaga mengurangi dampak iklim yang terjadi lingkungan, selain itu semangat yang terdapat dalam kegiatan Car Free Day dalah tempat untuk mengisi waktu luang dan melakukan kegiatan olahraga bagi masyarakat.

Program Car Free Day pertama kali dilakukan di negara Belanda dan Belgia dalam rangka mengurangi krisis energi pada tanggal 25 November 1956 hingga 20 Januari 1957. Pada tanggal 19 April 2001 program Earth Car Free Day (ECFD). Lebih dari 300.000 organisasi dan Kota diseluruh dunia ikut berpartisipasi dalam kegiatan yang diadakan The Commons WC/FD program and Earth Day Network. PBB telah menyatakan program Car Free Day (CFD) merupakan sebuah proyek dunia dalam rangka mengurangi pencemaran udara. Hal ini termuat dalam proposal PBB mengenai The United Nations Car Free Day (CFD) Programme Indonesia Program Car Free Day (CFD) dikenal dengan hari Bebas Kendaraan Bermotor (HBKB) dimana seluruh kendaraan yang mengandung atau menghasilkan bau knalpot seperti mobil, motor dan kendaraan dilarang melintas dijalan yang telah ditentukan.

Di Indonesia Pelaksanaan Car Free Day (CFD) pertama kali dilaksanakan di Jakarta pada bulan April tahun 2008, kemudian kegiatan ini mulai berkembang dan menjamur di Kota-kota besar seluruh Indonesia, seperti contoh Kota
Surabaya, Kota Semarang dan Kota Solo adalah contoh yang sudah mempraktekkan kegiatan Car Free Day hal ini bertujuan untuk memperbaiki kualitas udara akibat polusi kendaraan bermotor, dan juga bermanfaat bagi warga untuk sehat berolahraga.

Pelaksanaan Car Free Day (CFD) di Kota Surabaya, Kota Semarang dan Kota Surakarta sendiri dilaksanakan setiap hari minggu dimana dimulai pukul $05.00-09.00$.

Di Kota Surabaya memiliki Taman Bungkul, Taman ini mendapat penghargaan sebagai taman kota terbaik Se-Asia, tentu taman ini tak lepas dari sejarah unik, Taman Bungkul semakin dikenal oleh masyarakat yaitu program Car Free Day (CFD) yang diadakan setiap hari minggu pukul 06.0009.00. Taman Bungkul menjadi tempat favorit bagi masyarakat Kota Surabaya untuk mengadakan hari libur, ditempat ini ada yang beresepeda, sekedar jalan sehat ada juga yang melakukan jogging dan sepak bola serta da pula yang melakukan senam aerobik bersama.

Di Kota Semarang kegiatan Car Free Day (CFD) dipusatkan dikawasan Simpang Lima hingga Pahlawan, tema dan konsep Car Free Day (CFD) di Semarang diresmikan pada tanggal 19 Desember 2010, Car Free Day (CFD) seperti sebuah pasar rakyat dengan berbagai macam tema dan konsep. Selain sebagai program pengurangan polusi udara, CFD ini juga dijadikan ajang berkumpul dan beraktivitas warga Semarang dan sekitarnya. Di kawasan ini banyak menemui orang-orang yang berolahraga, senam, bersepeda dan masih banyak lagi. Pelaksanaan Car Free Day (CFD) di Kota Semarang dilaksanakan di Jalan Pemuda (Tugu Muda- Paragon), JL. Pandanaran juga. Hal ini sesuai dengan perwujudan Kota Semarang menuju Kota yang berwawasan lingkungan. Sedangkan, Car Free Day (CFD) di Kota Surakarta pertama kali dilaksanakan pada tanggal 30 Mei 2010 dan dibuka oleh Wakil Walikota Surakarta Bp. Fx. Rudianto. 
Pada awal pelaksanaannya, Solo Car Free Day diberlakukan di sepanjang jl. Slamet Riyadi (perempatan purwosari sampai bundaran gladak), yakni sejauh $3,74 \mathrm{~km}$. Kemudian pada perkembangannya, kegiatan ini diperluas tidak hanya sepanjang Jl. Slamet Riyadi, yakni dari perempatan Purwosari sampai bundaran gladak dan melebar di JL Dipenegoro (www. Surakarta.go.id). Disamping menyelenggarakan solo Car Free Day Kota Solo juga sebagai salah satu kota yang ikut dalam program pengembangan kota hijau atau green city dan berupaya dalam mewujudkan Kota Solo menjadi kota hijau atau green city.

Dalam perkembangannya di era modern ini Car Free Day salah satu bentuk dari peran pemerintah dalam upaya mengatasi minimnya tempat dan fasilitas untuk melakukan kegiatan olahraga rekreasi adalah dengan menerbitkan kebijakan Car Free Day (CFD). Sisi positif dari pelaksanaan Car Free Day terlihat dari partisipasi masyarakat dari kegiatan ekonomi dengan menjual makanan, pakaian, dan lain sebagainya. Sedangkan dari sisi olahraga banyak masyarakat yang memanfaatkan momen Car Free Day dalam melakukan aktivitas olahraga, selain itu klub atau komunitas tertentu "unjuk gigi" dalam menampilkan sesuatu yang menjadi nilai pemikat untuk bersosialisasi atau menampilkan seseuatu yang baru.

Terkait tentang olahraga yang dilakukan dikawasan Car Free day (CFD) menurut ilmuwan dari Belanda David Van Bodegom yang dilansir dari Sunday Times of London menyebutkan "Jika seseorang yang melakukan olahraga bersama orang-orang terdekat itu punya dampak positif untuk tubuh", Selain itu lebiih dari $70 \%$ orang yang mulai menjalankan program penurunan berat badan hanya berjalan 1 sampai 3 bulan saja. sepanjang program latihannya memang berat badan mereka turun, tapi setelah program itu berhenti berat badannya akan naik. Selain itu menurut Maoefris Kasim, tahun 2002 menyatakan"bahwa faktor kegemukan, kurang gerak, riwayat keluarga terkena penyakit kardiovaskular, serta penyakit diabetes mempunyai resiko terkena penyakit jantung coroner $4 \mathrm{X}$ lebih tinggi dibanding yang tidak menderita diabetes". WHO dalam memperingati Hari Kesehatan Dunia ke -54, pada tanggal 07 April 2002 menetapkan tema "Fit For Health" yang berkembang menjadi "Move For Health" yang diterjemahkan dalam Bahasa Indonesia menjadi "Bergerak Agar Sehat dan Bugar", artinya dengan adanya program Car Free Day yang dilakukan oleh pemerintah Kota (Surabaya, Semarang, Surakarta) memiliki hubungan atau berkorelasi tentang gaya hidup dan keaktifan masyarakatnya dalam pemenuhan kesehatan melalui olahraga yang diikuti atau dilakukan oleh masyarakatnya, Oleh karena itu kegiatan aktifitas fisik dan olahraga perlu menjadi gerakan masyarakat dalam menuju kesehatan massal.

Fenomena yang paling sering dijumpai banyaknya masyarakat yang sadar untuk melakukan kegiatan berolahraga dengan "gerak" bersama semisal senam aerobik, maupun senam yang dilakukan oleh komunitas tertentu. Seperti apa pelaksanaan kegiatan berolahraga yang dilakukan dikawasan Car Free Day ini menjadi sesuatu yang menarik untuk digambarkan dan dilakukan penelitian, beberapa tahun berjalan program CFD disini memunculkan sebuah pertanyaan.

Dengan adanya latar belakang diatas penulis mengambil pokok permasalahan yang menjadikan penting untuk diteliti dari penulis dengan mengambil judul "Fenomena dan Dampak Partisipasi Masyarakat dalam Berolahraga diKawasan Car Free Day (CFD) Di Kota Besar

\section{METODE PENELITIAN}

Pada penelitians ini merupakan penelitian kualitatif dengan menggunakan pendekatan deskriptif, data yang dikumpulkan terutama 
Journal of Sport and Exercise Science, Vol 2, No 1, 2019 (14-20)

Fenomena Dan Dampak Partisipasi Masyarakat Dalam Berolahraga Di Kawasan Car Free Day (CFD) Di Kota Besar (Studi Pada Kota Semarang, Surabaya, Surakarta)

berupa kata-kata, kalimat atau gambar yang memiliki arti lebih dari pada sekedar frekuensi. Peneliti menekankan catatan yang menggambarkan situasi sebenarnya guna mendukung penyajian data (Sutopo, 2002: 35).

Penelitian terfokus untuk menggali dan menelaah fenomena kegiatan olahraga yang dilakukan seseorang atau kelompok atau komunitas tertentu yang dilakukan dikawasan CFD di Kota besar yaitu Kota Surabaya, Semarang dan Surakarta. Penelitian ini menggunakan jenis desain korelasional yang tujuannya adalah menghubungkan dua variabel atau lebih (Maksum, 2012:105), dalam hubungan antar variabel ini termasuk hubungan timbal balik atau resiprokal. Hubungan timbal balik terjadi manakala suatu variabel menjadi penyebab sekaligus akibat dari variabel yang lain. Secara skematik model hubungan tersebut dapat digambarkan, sebagai berikut:

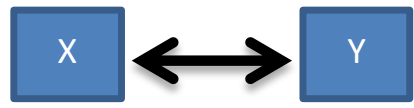

\section{Keterangan :}

$\mathbf{X}$ : Partisipasi Masyarakat Berolahraga

Y : Car Free Day (Maksum, 2012: 115)

Dalam penelitian ini, peneliti berusaha untuk menelaah sebanyak mungkin data mengenai fenomena CFD serta dampak yang terjadi didalamnya khususnya aktifitas olahraga .

Sumber data dalam penelitian ini adalah kawasan Car Free Day di Kota besar khususnya Kota Surabaya, Kota Semarang dan Kota Surakarta. Pemilihan 3 Kota tersebut memiliki alasan tertentu, yaitu :

a. Salah satu Kota besar dengan penduduk yang banyak.

b. Heterogenitas masyakat dikota besar.

c. Banyaknya komunitas tertentu yang melakukan olahraga dengan berbagai motif dan tujuan.

Sumber data dalam penelitian ini bukan sebagai yang mewakili populasinya tetapi cenderung mewakil informasinya. menurut Lofland dan Lofland (1984:47) dalam Moleong, sumber data utama dalam penelitian kualitatif ialah kata-kata, dan tindakan selebihnya adalah data tambahan seperti dokumen dan angket.

Sumber data yang digunakan dalam penelitian ini adalah data primer yaitu data yang diperoleh oleh peneliti secara langsung dari sumber aslinya yaitu, orang, kelompok atau komunitas tertentu yang melakukan olahraga di kawasan Car Free Day. Sumber data dalam penelitian ini ada beberapa kriteria yang menjadi subjek yang biasa digunakan, adalah sebagai berikut :

a. Orang-orang yang melakukan aktivitas gerak atau olahraga tertentu.

b. Kelompok atau komunitas yang rutin melakukan gelaran olahraga di kawasan CFD.

c. Masyarakat umum yang melakukan aktivitas berolahraga.

Dalam penelitan ini menggunakan purposive sample atau sampel bertujuan, adalah sebuah teknik pengambilan sampel yang ciri atau karakteristiknya sudah diketahui lebih dulu berdasarkan ciri atau sifat populasi. Kriteria sampel tersebut diantaranya, adalah :

1. Komunitas atau kelompok olahraga di area Car Free Day.

2. Masyarakat umum yang gemar melakukan olahraga diarea Car Free Day.

3. Jenis olahraga yang dilakukan

Dalam penelitian ini menggunakan purposive sample atau sampel bertujuan, adalah sebuah teknik pengambilan sampel yang ciri atau karakteristiknya sudah diketahui lebih dulu yaitu 1. Orang atau kelompok tersebut melakukan olahraga dikawasan car free day, 2. Mereka melakukannya antara pukul 05.30-09.00, dibuka hingga ditutupnya CFD tersebut. Jumlah sampel yang diambil berjumlah 77 orang dengan rincian 38 orang diKota Semarang dan 39 sampel dikota 
Surabaya. Sampel ini dipilih berdasarkan kriteria di atas dan dengan prosedur sebagai berikut :

1. Orang atau kelompok tersebut selesei melakukan olahraga dengan tidak mengganggu kegiatan aktivitas mereka.

2. Peneliti menawarkan, apakah orang atau kelompok tersebut bersedia untuk diwawancarai atau mengisi kuesioner?

3. Setelah mereka mau diwawancarai, peneliti mencatat sesuai dengan pertanyaan yang sudah disiapkan

4. Kalaupun mereka tidak mau, mereka bersedia untuk mengisi kuesioner yang sudah disiapkan

Indikator dalam membuat angket CFd sebagai berikut:

Tabel 1. Indikator Angket.

\begin{tabular}{|c|c|c|}
\hline No & Indikator & Keterangan \\
\hline 1. & Intrinsik & $\begin{array}{l}\text { - Olahraga } \\
\text { - Menjaga Kesehatan } \\
\text { - Refreshing } \\
\text { - Menghilangkan } \\
\text { Kejenuhan }\end{array}$ \\
\hline 2. & Ekstrinsik & $\begin{array}{l}\text { - Teman } \\
\text { - Lokasi } \\
\text { - Biaya } \\
\text { - Cuaca } \\
\text { - Peran Pemerintah }\end{array}$ \\
\hline 3. & Jenis Sampel & $\begin{array}{l}\text { - Perorangan } \\
\text { - Kelompok }\end{array}$ \\
\hline 4. & Kriteria & $\begin{array}{l}\text { Sesuai syarat pada focus } \\
\text { penelitian }\end{array}$ \\
\hline
\end{tabular}

\section{HASIL}

Hasil deskripsi dari keseluruhan data dari kuesioner yang dibagikan kepada subjek penelitian. Kuesioner yang diberikan secara langsung kepada responden dengan menunggu saat pengisian kuesioner dan secara langsung mengumpulkan kuesioner yang telah diisi, dapat dilihat pada tabel diberikut ini :
Tabel 2. Jumlah sampel.

\begin{tabular}{clcl}
\hline No & Kota & $\begin{array}{c}\text { Jumlah } \\
\text { Sampel }\end{array}$ & \multicolumn{1}{c}{ Keterangan } \\
\hline 1. & $\begin{array}{l}\text { Kota } \\
\text { Semarang }\end{array}$ & 26 & $\begin{array}{l}\text { Pengunjung } \\
\text { yang melakukan } \\
\text { olahraga di CFD }\end{array}$ \\
\hline 2. & $\begin{array}{l}\text { Kota } \\
\text { Surabaya }\end{array}$ & 26 & $\begin{array}{l}\text { Pengunjung } \\
\text { yang melakukan } \\
\text { olahraga di CFD }\end{array}$ \\
\hline 3. & $\begin{array}{l}\text { Kota } \\
\text { Surakarta }\end{array}$ & 25 & $\begin{array}{l}\text { Pengunjung } \\
\text { yang melakukan } \\
\text { olahraga di CFD }\end{array}$ \\
\hline
\end{tabular}

Tabel 3. Jumlah keseluruhan kuesioner yang dibagikan pada responden.

\begin{tabular}{lcc}
\hline \multicolumn{1}{c}{ Informasi } & Frekuensi & Prosentase \\
\hline Distribusi Kuesioner & 77 & $100 \%$ \\
\hline Kuesioner yang kembali & 77 & $100 \%$ \\
\hline Kuesioner yang gugur & 0 & $0 \%$ \\
\hline $\begin{array}{l}\text { Kuesioner yang dapat } \\
\text { digunakan }\end{array}$ & 77 & $100 \%$ \\
\hline
\end{tabular}

Data diatas dapat dilihat bahwa kuesioner yang dikembalikan adalah $100 \%$, sedangkan kuesioner yang tidak dikembalikan $0 \%$ dari kuesioner yang dapat diproses dalam penelitian ini adalah 100\%. Berikut adalah hasil penghitungan menggunakan SPSS dalam mengolah data ada bagian Hasil dan pembahasan membahas tentang hasil penelitian. 
Journal of Sport and Exercise Science, Vol 2, No 1, 2019 (14-20)

Fenomena Dan Dampak Partisipasi Masyarakat Dalam Berolahraga Di Kawasan Car Free Day (CFD) Di Kota Besar (Studi Pada Kota Semarang, Surabaya, Surakarta)

Tabel 4. Hasil Statistik Deskriptif Jawaban dari Responden.

\begin{tabular}{lcccccc}
\hline \multicolumn{1}{c}{ Variabel } & $\mathbf{N}$ & $\begin{array}{c}\text { Olahraga } \\
\text { yang } \\
\text { dilakukan }\end{array}$ & $\begin{array}{c}\text { Waktu di } \\
\text { CFD }\end{array}$ & $\begin{array}{c}\text { Rata-rata } \\
\text { selesei } \\
\text { aktifitas diCFD }\end{array}$ & $\begin{array}{c}\text { Rata-rata } \\
\text { waktu yang } \\
\text { dihabiskan }\end{array}$ & $\begin{array}{c}\text { Standart } \\
\text { Deviasi }\end{array}$ \\
\hline Jenis Olahraga & 77 & $5-10$ & $9-22$ & 15 & 14,62 & 3,035 \\
\hline $\begin{array}{l}\text { Kelompok atau } \\
\text { Individu }\end{array}$ & 77 & $6-20$ & $15-17$ & 18 & 20,51 & 3,227 \\
\hline $\begin{array}{l}\text { Olahraga dengan } \\
\text { waktu yang } \\
\text { panjang }\end{array}$ & 77 & $7-20$ & $21-20$ & 21 & 28,51 & 3,247 \\
\hline $\begin{array}{l}\text { Intensitas } \\
\text { Dampak }\end{array}$ & 77 & $6-20$ & $13-20$ & 18 & 23,79 & 3,118 \\
\hline
\end{tabular}

\section{PEMBAHASAN}

Berikut adalah diskusi pembahasan hasil dari penelitian secara deskriptif sebagai berikut

a. Pada pertanyaan nomer $1,6,11,16$ adalah fokus pada jenis olahraga yang dilakukan yaitu, rata2 masyarakat yang datang ke CFD dengan datang berkelompok untuk mengikuti beberapa olahraga yang ada di CFD dengan membawa peralatan yang dibawa dari rumah seperti sepeda, bola basket, skipping dll,

b. Untuk pertanyaan 2, 7, 12, 17 adalah tentang fokus pertanyaan pada kelompok atau individu Masyarakat yang berangkat ke CFD adalah lebih sering berkelompok bersama teman dan bergabung dengan orang lain yang mempunyai kesamaan hobi atau olahraga yang sejenis semisal, senam aerobik, jogging bareng atau bersepeda bersama.

c. Pada pertanyaan $3,8,13,18$, tentang lama berolahraga di CFD adalah Pengunjung CFD menghabiskan waktu lebih dari 1 jam dan rata2 mereka berngkat dari rumah lebih dari jam 06.00 dan sesampainya dirumah pukul 09.00 lebih, jadi rata2 yang dihabiskan di kawasan CFD rata-rata lebih dari 2 jam

d. Tentang intensitas atau rutinitas terdapat pada pertanyaan 4, 9, 14, 19 adalah Masyarakat dikota besar sering mengunjungi
CFD untuk berolahraga rata2 mereka datang lebih dari $2 X$ dalam 1 bulan, dan rata 2 masyarakat mengabiskan waktu kurang dari 3 jam untuk berada di CFD berangkat hingga pulang

e. Sedangkan pada pertanyaan 5, 10, 15 dan 20 tentang dampak yang dialami Para pengunjung CFD merasa senang saat mengikuti olahraga di kawasan CFD mereka merasa terhibur dan mendapatkan semangat dan motivasi baru setelah melakukan olahraga dikawasan CFD.

\section{SIMPULAN DAN REKOMENDASI}

Dengan adanya program CFD yang dilakukan oleh pemerintah memberikan dampak yang positif khususnya bagai masyarakat yang datang, hal ini terbukti sebanyak $72 \%$ responden merasa mendapatkan semangat dan motivasi baru sepulang dari olahraga dikawasan CFD.

Kegiatan CFD ini setidaknya dilakukan disemua daerah dikota besar di Indonesia hal ini dikarenakan, selain mengikuti CFD, masyarakat juga bisa melakukan olahraga, rekreasi maupun menikmati hiburan yang berada di CFD.

Setelah mengetahui hasil penelitian ini, hendaknya pemangku kebijakan memberikan kebijakan tentang pelaksanaan CFD disemua Kota maupun Kabupaten yang ada dilndonesia, 
bahwasannya CFD merupakan sarana dalam mendukung hidup sehat dengan berolahraga pada masyarakat Indonesia

Program ini bisa dilakukan diJalan protokol suatu daerah tertentu, selain CFD hal ini ini merupakn wahana wisata keluarga untuk hidup sejahtera dan sehat dengan mendukung program pemerintah ke depannya.

\section{REFERENSI}

Giriwijoyo, S. dan Sidik, D.Z. 2013. Ilmu Faal Olahraga. Bandung : Remaja Rosdakar

Ginanjar, A. 2012. Serba Tahu Dunia Olahraga.Surabaya : Dafa Publishing

KBBI Online, 2010

Sugiyono. (2015) Memahami Metode Penelitian Kualitatif. Bandung: Alfabeta

Sutopo, H.B. 2002. Metodologi Penelitian Kualitatif. Surakarta: Universitas Sebelas Maret

Peraturan Walikota Semarang nomor 22 tahun 2011 Tentang Pelaksanaan Hari Bebas Kendaraan Bermotor

Peraturan Pemerintah nomor 41, tahun 1999 tentang Pengendalian Pencemaran Udara

Peraturan Walikota Surabaya No 74 tahun 2013, tentang Penyelenggaraan Hari Bebas Kendaraan Bermotor

Toho Cholik Mutohir \& Ali Maksum. 2007. Sport Developmen Index. Jakarta: PT. Index.

Undang-Undang Republik Indonesia Nomer 3 tahun 2005. Sistem Keolahragaan Nasional.

Jakarta : CV. Eko jaya 